\title{
A novel immunoradiometric assay for human liver ferritin
}

\author{
A AL-SHAWI, ANNE DAWNAY, J LANDON \\ From the Department of Chemical Pathology, St Bartholomew's Hospital, London EC1
}

SUMMARY Rivanol, the cationic salt of an acridine base, has been used as a novel separation procedure in an immunoradiometric assay for human liver ferritin. The separation step is based on the differences in charge and molecular weight between the labelled antibody-ferritin complex and free labelled immunoglobulins. The resultant assay is simple, reproducible and sufficiently sensitive to determine serum concentrations of ferritin.

All immunoradiometric assays (IRMA) are based on the use of specific antibodies labelled with a radionuclide and offer several advantages as compared with radioimmunoassays (RIA), which employ isotopically labelled antigen. ${ }^{12}$ In a conventional IRMA, of the type first described by Miles and Hales, ${ }^{34}$ sample (or standard) is incubated with an excess of the labelled antibodies and, once equilibrium has been reached, it is necessary to separate the remaining free labelled antibodies from those bound to the antigen. To date this has always been achieved by the addition of an immunoadsorbent comprising antigen covalently coupled to a solid phase.

Such a separation step is wasteful of purified antigen and prohibits the use of conventional IRMA for analytes that are either expensive or in short supply. This disadvantage is avoided in IRMA of the "twosite sandwich" type in which unlabelled antibodies coupled or adsorbed to a solid phase are used to bind all the antigen present in the sample (or standard) and the labelled specific antibodies to determine how much has been bound. ${ }^{5}$ However, this approach is limited to analytes having more than one antigenic determinant and is wasteful of antisera. As an alternative, it seemed likely that differences in charge and/or molecular weight between the antigen-labelled antibody complex and free labelled antibodies in some conventional IRMA might enable use of a simpler separation technique.

Horejsi and Smetana ${ }^{6}$ have shown that it is possible to precipitate all the main plasma proteins, other than the gamma globulins, by addition of a carefully chosen amount of rivanol at neutral or

Accepted for publication 16 November 1982 slightly alkaline $\mathrm{pH}$. The present paper describes a simple conventional IRMA for the iron storage protein, ferritin, in which rivanol is used to precipitate the ferritin-antibody complex while leaving the free labelled antibodies in the supernatant.

\section{Material and methods}

Rivanol, the cationic salt of the acridine base, 2-ethoxy 6,9-diaminoacridine lactate monohydrate, was supplied as a yellow powder of more than $97 \%$ purity by Koch-Light (Colnbrook, Berkshire); Sepharose 6B was obtained from Pharmacia (Hounslow, Middlesex); bovine serum albumin (BSA) and glutaraldehyde from Sigma (Poole, Dorset); potassium thiocyanate and potassium ferrocyanide from BDH (Poole, Dorset); human serum albumin (HSA) from Kabi (Stockholm, Sweden); Coomassie brilliant blue (R250) from Biorad (Richmond, USA); iodogen from Pierce Chemical (Rockford, USA); and carrier free $\mathrm{Na}^{125}$ I from Amersham International (Amersham, Buckinghamshire).

PREPARATION OF HUMAN LIVER FERRITIN

Ferritin was extracted and purified from human liver by a slight modification of the method of Aherne and Worwood. ${ }^{7}$ Thus the product from this method was chromatographed on a Sepharose $6 \mathrm{~B}$ column

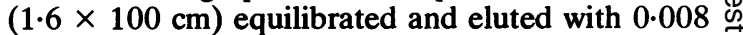
$\mathrm{M} \mathrm{Na} \mathrm{HPO}_{4} / 0.002 \mathrm{M} \mathrm{NaH}_{2} \mathrm{PO}_{4}$ adjusted to $\mathrm{pH} 7.5$ with $1 \mathrm{M} \mathrm{NaOH}$. The protein content of the final product was determined by the method of Lowry and his colleagues ${ }^{8}$ using HSA as a standard. Its purity was determined by $4 \%$ (wt/vol) polyacrylamide gel electrophoresis using glycine Tris buffer, $\mathrm{pH} 8.5$ as described in a commercial instruction 440 
manual (Shandon Southern Instruments, Runcorn, Cheshire). The gels were run in duplicate and one was stained for ferric iron using potassium ferrocyanide $^{9}$ and the other for protein, with Coomassie brilliant blue. There was one main band representing the ferritin monomer and a smaller band due to ferritin polymer. The highly purified human liver ferritin was used as the immunogen, to prepare standards and as the immunoadsorbant.

\section{PREPARATION OF SHEEP ANTIFERRITIN}

\section{IMMUNOGLOBULINS}

Three Border-Leicester ewes were each injected intramuscularly at several sites with human ferritin ( $200 \mu \mathrm{g}$ in $2 \mathrm{ml}$ of water) emulsified with complete Freund's adjuvant $(6 \mathrm{ml})$. The sheep were reimmunised at seven week intervals, each with $100 \mu \mathrm{g}$ of ferritin in incomplete Freund's adjuvant, and bled 10 days after each reimmunisation. All produced high titre antisera and the third bleed from one sheep (S-457-3) was used for all subsequent studies.

The specific antiferritin immunoglobulins from 1 $\mathrm{ml}$ of antiserum were extracted with $8 \mathrm{mg}$ of immunosorbant, comprising human ferritin that had been polymerised using glutaraldehyde at a glutaraldehyde to ferritin ratio of $1: 10(\mathrm{wt} / \mathrm{wt}){ }^{10}$ After washing, the specific antibodies were eluted from the immunoadsorbant by use of $3 \mathrm{M}$ potassium thiocyanate in $0.05 \mathrm{M} \mathrm{NaH}_{2} \mathrm{PO}_{4}$ adjusted to $\mathrm{pH} 6.0$ with $1 \mathrm{M} \mathrm{NaOH} .{ }^{11}$

\section{RADIOIODINATION OF SPECIFIC ANTIFERRITIN IMMUNOGLOBULINS}

The purified sheep antiferritin immunoglobulins were radioiodinated by the iodogen technique. ${ }^{12}$ Briefly, $50 \mu \mathrm{l}$ of iodogen solution $(40 \mu \mathrm{g} / \mathrm{ml}$ in dichloromethane) were allowed to evaporate to dryness in the bottom of a polypropylene tube. Iodine-125 ( $\left.{ }^{125} \mathrm{I}\right)(\mathrm{ImCi}, 0.5 \mathrm{nmol})$ was added followed by $38 \mu \mathrm{g}$ $(0.25 \mathrm{nmol})$ of purified antibody in $38 \mu \mathrm{l}$ of $0.1 \mathrm{M}$ sodium phosphate buffer, $\mathrm{pH} 7 \cdot 5$. The reaction was terminated after $10 \mathrm{~min}$ by transferring the reaction mixture to $500 \mu \mathrm{l}$ of $0.05 \mathrm{M}$ sodium phoshate buffer, $\mathrm{pH} \mathrm{7.5}$. After a further $10 \mathrm{~min}$ the iodination mixture was chromatographed on a Sephadex G200 column $(0.9 \times 60 \mathrm{~cm})$ previously equilibrated with $0.04 \mathrm{M} \mathrm{Na}_{2} \mathrm{HPO}_{4} / 0.01 \mathrm{M} \mathrm{NaH}_{2} \mathrm{PO}_{4}$ adjusted to $\mathrm{pH}$ 7.5 with $1 \mathrm{M} \mathrm{NaOH}$, containing BSA $(0.5 \% \mathrm{wt} / \mathrm{vol})$ and sodium azide $(0 \cdot 2 \% \mathrm{wt} / \mathrm{vol})$. The fractions from the peak comprising the ${ }^{125}$ I labelled immunoglobulins were pooled and stored at $-20^{\circ} \mathrm{C}$.

In a series of 10 radioiodinations, the mean $( \pm \mathrm{SD})$ incorporation of ${ }^{125} \mathrm{I}$ was $70.5 \pm 3.5 \%$ and the specific activity of the labelled product ranged from 17.6 to $19.5 \mu \mathrm{Ci} / \mu \mathrm{g}$ of IgG. The labelled product was stable for at least $10 \mathrm{wk}$ at $-20{ }^{\circ} \mathrm{C}$ and more than $65 \%$ bound to an excess of the immunoadsorbant.

\section{SAMPLES AND STANDARDS}

Serum samples from 91 patients were provided by Dr S Woodhead of the Welsh School of Medicine. These had all been assayed by a "two-site" immunoradiometric automated technique (S Woodhead, personal communication, 1982).

Ferritin-free serum was obtained by incubating pooled normal human serum with sheep antiferritin serum covalently coupled to magnetisable particles as described previously. ${ }^{13}$ After overnight rotatory mixing, the particles were sedimented on a magnetic block and the serum supernatant demonstrated to contain no measurable ferritin. Sodium azide was added $(0.2 \%)$ and $10 \mathrm{ml}$ aliquots stored at $-20^{\circ} \mathrm{C}$.

Highly purified ferritin standards were prepared in standard buffer $(0.05 \mathrm{M}$ sodium phosphate buffer, $\mathrm{pH} 7 \cdot 5$, containing BSA $(4 \%)$ ) at a concentration of $1000 \mu \mathrm{g} / \mathrm{l}$ and stored in $0.5 \mathrm{ml}$ aliquots at $-20^{\circ} \mathrm{C}$

\section{ASSAY PROTOCOL}

Patients' samples (previously diluted $1 / 10$ in standard buffer) or standards, ranging from 0.5 to 1000 $\mu \mathrm{g} / \mathrm{l}(100 \mu \mathrm{l})$ were incubated with $150 \mu \mathrm{l}$ of ${ }^{125} \mathrm{I}-$ labelled specific antiferritin antibodies (sufficient to give $100000 \mathrm{cpm})$ in assay buffer $(0.5 \mathrm{M}$ sodium phosphate buffer, $\mathrm{pH} 7.5$ containing $0.1 \%$ BSA) at room temperature.

After equilibrium had been reached the rivanol solution in $0.05 \mathrm{M}$ sodium phosphate buffer $\mathrm{pH} 7.5$ was added and, after a short further incubation period, the tubes were centrifuged, the supernates decanted and the precipitates (containing the ferritin-anti-ferritin-complex) counted for $60 \mathrm{~s}$.

\section{Results}

STUDIES OF THE RIVANOL SEPARATION STEP Horejsi and Smetana ${ }^{6}$ have demonstrated the critical importance of $\mathrm{pH}$ and of the volume and concentration of rivanol in the differential precipitation of plasma proteins. Therefore, studies were undertaken of the rivanol separation step by employing tubes containing the top standard $(1000 \mu \mathrm{g} / \mathrm{l})$ and excess labelled specific antibodies and, in others, labelled antibodies in the absence of human liver ferritin. A concentration of $0.05 \%$ rivanol was chosen on the basis of initial experiments and from 50 to $1250 \mu \mathrm{l}$ was added to each tube. Less than $5 \%$ of the labelled antibodies alone were precipitated but addition of $1 \mathrm{ml}$, or more, resulted in complete precipitation of the ferritin-antibody complex (Fig. 1). Next, $1 \mathrm{ml}$ of $0.05 \%$ rivanol in a range of buffers 


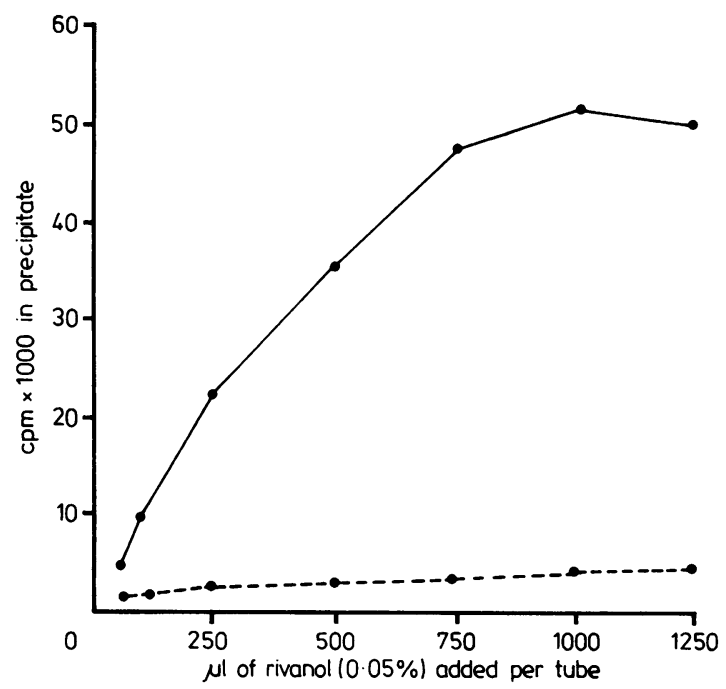

Fig. 1 Assessment of the effect of the volume of rivanol used to achieve separation of the bound and free fractions. Tubes contained excess labelled antiferritin antibodies both

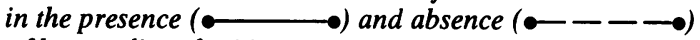
of human liver ferritin.

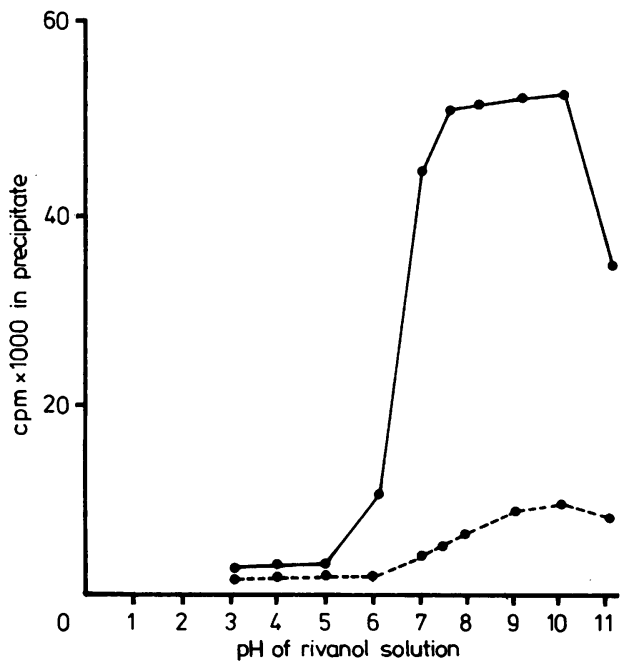

Fig. 2 Assessment of the effect of the pH of the rivanol solution used to achieve separation of the bound and free fractions. Tubes contained excess labelled antiferritin antibodies both in the presence $(\bullet \longrightarrow$ ) and absence (०- - - $\bullet$ ) of human liver ferritin.

was added. Neither the free labelled antibodies nor the antigen-antibody complex were precipitated over the $\mathrm{pH}$ range 3-5. However, separation was achieved between pH 7.5 and 10 (Fig. 2) and phosphate buffer, $\mathrm{pH} 7.5$ was chosen in order to minimise non-specific precipitation.
In further experiments it was shown necessary to leave the tubes $10 \mathrm{~min}$ after the addition of the rivanol before centrifugation and that separation was not improved by longer periods up to $24 \mathrm{~h}$. Centrifugation for $10 \mathrm{~min}$ at $1000 \mathrm{rpm}$ was sufficient to ensure maximum precipitation whether at $4^{\circ}, 25^{\circ}$, or $37^{\circ} \mathrm{C}$.

OPTIMISATION AND VALIDATION OF ASSAY Standard curves were set up and incubated for from $10 \mathrm{~min}$ to $8 \mathrm{~h}$. Equilibrium was attained in $120 \mathrm{~min}$ when the standard curve covered the clinically important range for diagnosing iron deficiency ${ }^{14}$ (Fig. 3). Use of four different amounts of the ${ }^{125} \mathrm{I}-$ specific antibodies was studied and that sufficient to give $100000 \mathrm{cpm}$ found most suitable. Use of 100 $\mu l$ of undiluted ferritin-free serum affected the assay non-specifically but this was avoided by diluting all samples $1 / 10$, or more, in phosphate buffer, $\mathrm{pH} 7 \cdot 5$, containing BSA (4\%).

The sensitivity of the IRMA, as determined by the method of Rodbard, ${ }^{15}$ was $10 \mu \mathrm{g} / 1$ of serum and, by appropriate sample dilution, it was possible to assay all samples. Recovery, as determined by adding from $1 \mu \mathrm{g} / \mathrm{l}$ to $125 \mu \mathrm{g} / \mathrm{l}$ of human liver ferritin to three serum pools was in the range of 92.1 to $106.1 \%$. Within-assay variation as assessed by assaying four individual samples 10 times in an assay ranged from 2.7 to $8.0 \%$; the between-assay coefficient of variation for the same samples assayed in duplicate in 10 different assays ranged from 3.3 to $10.0 \%$ (Table 1 ).

Of the 91 patient samples, 25 had been recorded as having values either $<10 \mu \mathrm{g} / 1$ or $>6000 \mu \mathrm{g} / \mathrm{l}$ by the automated "two-site" IRMA. Our results were

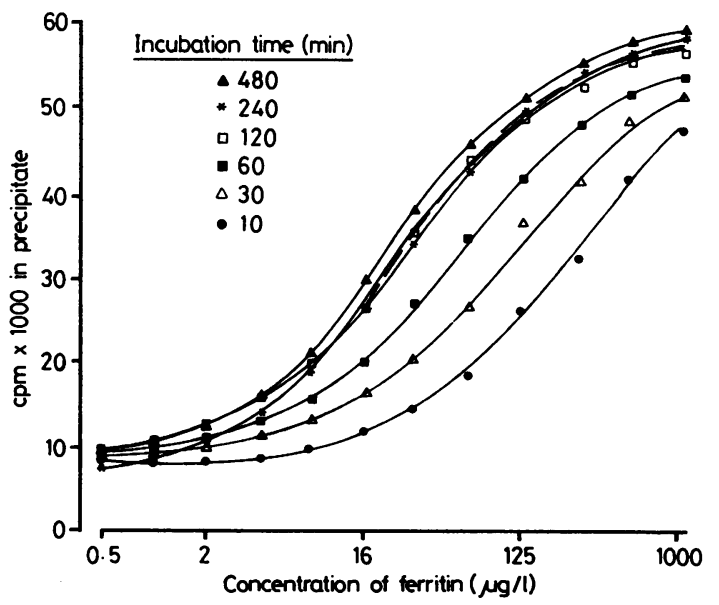

Fig. 3 Assessment of the effect of incubation time, prior to the addition of rivanol, on the standard curve. 
Table 1 Precision data

\begin{tabular}{|c|c|c|c|c|c|}
\hline \multirow[t]{2}{*}{ Sample No } & \multicolumn{2}{|l|}{ Within-assay variation } & \multicolumn{3}{|l|}{ Between-assay variation } \\
\hline & $\begin{array}{l}\text { Serum ferritin }(\mu g / l) \\
\text { Mean } \pm S D(n=10)\end{array}$ & $C V(\%)$ & $\begin{array}{l}\text { Serum ferritin }(\mu g / l) \\
\text { Mean } \pm S D(n=10)\end{array}$ & $C V(\%)$ & \\
\hline $\begin{array}{l}1 \\
2 \\
3 \\
4\end{array}$ & $\begin{array}{cc}249 & \pm 7 \\
156 & \pm 10 \\
59 & \pm 3 \\
16.7 & \pm 1.3\end{array}$ & $\begin{array}{l}2 \cdot 7 \\
6 \cdot 2 \\
5 \cdot 6 \\
8 \cdot 0\end{array}$ & $\begin{aligned} 250 & \pm 8 \\
151 & \pm 7 \\
59 & \pm 4 \\
15 \cdot 9 & \pm 1 \cdot 6\end{aligned}$ & $\begin{array}{r}3 \cdot 3 \\
5 \cdot 5 \\
6 \cdot 7 \\
10 \cdot 0\end{array}$ & \\
\hline
\end{tabular}

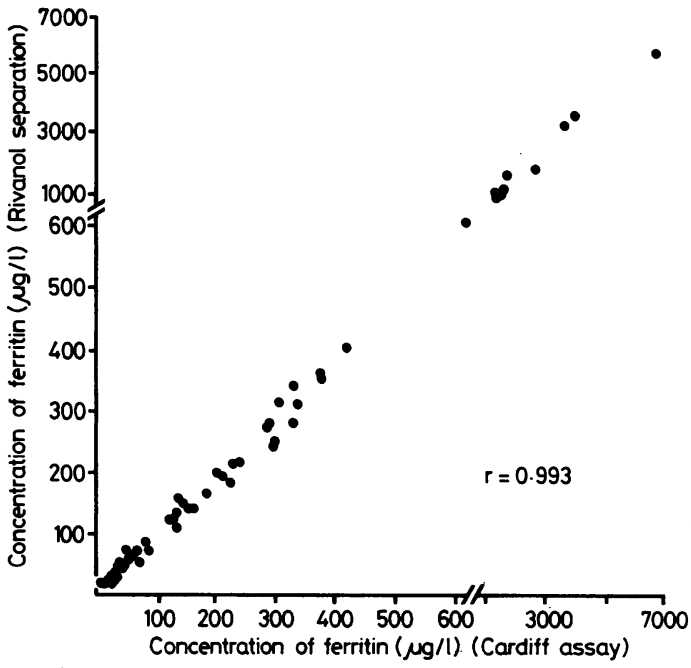

Fig. 4 Correlation between the results cbtained on 66 samples by the Cardiff assay and by our assay using rivanol separation.

in agreement with this. A comparison of the results obtained with the present assay for the remaining 66 samples is shown in Fig. 4.

\section{Discussion}

It has been assumed that the only means of separating excess free labelled specific antibodies from the antigen-labelled antibody complex in a conventional IRMA is by means of an immunosorbant which limits this analytical approach to analytes that are inexpensive and widely available. Ferritin is a much larger molecule than IgG and it seemed likely that simpler means could be devised for the separation step. Selective precipitation of the antigen-antibody complex seemed one obvious approach and, in the present study, rivanol has proved suitable for this purpose. The resultant assay is simple, rapid and sufficiently sensitive and precise for clinical purposes.

There is no doubt that other means of selectively precipitating the bound fraction could be devised and chromatographic techniques would clearly separate labelled antibodies bound to ferritin and free labelled antibodies. Many compounds of clinical relevance are of a much smaller size than ferritin and the development of alternative separation techniques in conventional IRMA for such compounds would be more difficult. However, once it has been recognised that the use of immunosorbants does not represent the only separation technique available, it should not be difficult to devise suitable alternatives. For example, rhematoid factor and Clq bind antibodies that have themselves bound their specific antigen, but do not bind free antibodies and several separation techniques based on such factors suggest themselves.

\section{References}

' Landon J, Mohamed-Ali S, Al-Shawi A, Nargessi RD. Use of labelled antibodies in immunoassays. Seventh Annual Meeting Clinical Radioassay Society 1981; No 7, 9-27.

2 Al-Shawi A, Mohamed-Ali S, Houts T, Hodgkinson S, Nargessi RD, Landon J. Labelled antibody immunoassays. Ligand Quarterly 1982; (in press).

${ }^{3}$ Miles LEM, Hales CN. The preparation and properties of purified 12sI-labelled antibodies to insulin. Biochem $J$ 1968;108:616-8.

4 Miles LEM, Hales CN. Labelled antibodies and immunological assay systems. Nature 1968;219:186-9.

${ }^{5}$ Miles LEM. Properties, variants and applications of the immunoradiometric assay methods. Ric Clin Lab 1975;5:5971 .

- Horejsi J, Smetana R. The isolation of gammaglobulin from blood serum by rivanol. Acta Med Scand 1956;155:65-70.

' Aherne W, Worwood M. Some properties of human serum ferritin. Biochem Soc Trans 1974;2:429-32.

${ }^{8}$ Lowry OH, Rosebrough NJ, Farr AL, Randall RJ. Protein measurement with the folin phenol reagent. J Biol Chem 1951;193:265-75.

${ }^{9}$ Marcus DM, Zinberg N. Isolation of ferritin from human mammary and pancreatic carcinomas by means of antibody immunoadsorbents. Arch Biochem Biophys 1974;162:493501.

${ }^{10}$ Arrameas S, Ternynck TH. The cross-linking of proteins with glutaraldehyde and its use for the preparation of immunoadsorbant. Immunochemistry 1969;6:53-66.

"Dandliker WB, Alonso R, De Saussure VA, Kierszenbaum F, Levison SA. The effect of chaotropic ions on the dissociation of antigen-antibody complexes. Biochem 1967;6:1460-7.

12 Salacinski PRP, McLean C, Sykes JEC, Clement-Jones VV, Lowry PJ. Iodination of proteins, glycoproteins, and peptides using a solid-phase oxidising agent, 1, 3, 4, 6-tetrachloro-3 $\alpha$, 
6 $\alpha$-diphenyl glycoluril (Iodogen). Anal Biochem 1981;117:136-46.

${ }^{13}$ Pourfarzanch M, White GW, Landon J, Smith DS. Cortisol directly determined in serum by fluoroimmunoassay with magnetisable solid phase. Clin Chem 1980;26:730-3.

14 Jacobs A, Miller F, Worwood M, Beamish MR, Wardrop CA. Ferritin in the serum of normal subjects and patients with iron deficiency and iron overload. Br Med J 1972;iv:206-8. is Rodbard D, Weiss GH. Mathematical theory of immunoradiometric (labelled antibody) assays. Anal Biochem 1973;52:10-44.

Requests for reprints to: Professor J Landon, Department of Chemical Pathology, St Bartholomew's Hospital, London EC1, England. 